\title{
Three-Dimensional Cephalometric Evaluation of Maxillary Growth following in utero Repair of Cleft Lip and Alveolar-Like Defects in the Mid-Gestational Sheep Model
}

\author{
Moschos A. Papadopoulos ${ }^{a}$ Nikolaos A. Papadopulos ${ }^{b}$ Christina Jannowitz $^{c}$ \\ Peter Boettcher $^{d}$ Julia Henke ${ }^{c}$ Rudolf Stolla ${ }^{e}$ Hans-Florian Zeilhofer $^{f}$ \\ Laszlo Kovacs $^{\mathrm{b}}$ Edgar Biemer ${ }^{\mathrm{b}}$ \\ ${ }^{a}$ Department of Orthodontics, School of Dentistry, Aristotle University of Thessaloniki, Thessaloniki, Greece; \\ ${ }^{b}$ Department of Plastic and Reconstructive Surgery, and ${ }^{\mathrm{c}}$ Institute of Experimental Oncology and Therapy \\ Research, Technical University Munich, and ${ }^{\mathrm{d}}$ Department of Small Animal Surgery and Institute of Veterinary \\ Anatomy and ${ }^{\mathrm{e}}$ Clinic for Veterinary Gynaecology and Obstetrics, Ludwig-Maximilians University Munich, and \\ ${ }^{f}$ Department of Oral and Maxillofacial Surgery, University of Basel, Switzerland and Center of Advanced Studies \\ on Craniomaxillofacial Surgery, Technical University Munich, Munich, Germany
}

\section{Key Words}

Cleft lip and palate $\cdot$ Intrauterine surgery ·

Mid-gestational sheep model $\cdot$ Fetal bone graft • Maxillary growth · Three-dimensional computed tomography $\cdot$ Three-dimensional cephalometric analysis

\begin{abstract}
Objective: To evaluate maxillary growth following in utero repair of surgically created cleft lip and alveolar (CLA)like defects by means of three-dimensional (3D) computer tomographic (CT) cephalometric analysis in the mid-gestational sheep model. Methods: In 12 sheep fetuses a unilateral CLA-like defect was created in utero (untreated control group: 4 fetuses). Four different bone grafts were used for the alveolar defect closure. After euthanasia, CT scans of the skulls of the fetuses, 3D re-
\end{abstract}

This study has received the Annual Scientific Award of the Association of German Plastic Surgeons for the year 2004.

\section{KARGER}

Fax +4161306 1234 E-Mail karger@karger.ch www.karger.com
(C) 2006 S. Karger AG, Basel

$1015-3837 / 06 / 0211-0105 \$ 23.50 / 0$

Accessible online at: www.karger.com/fdt constructions, and a 3D-CT cephalometric analysis were performed. Results: The comparisons between the operated and nonoperated skull sides as well as of the maxillary asymmetry among the experimental groups revealed no statistically significant differences of the 12 variables used. Conclusions: None of the surgical approaches used for the in utero correction of CLA-like defects seem to affect significantly postsurgical maxillary growth; however, when bone graft healing takes place, a tendency for almost normal maxillary growth can be observed.

Copyright $@ 2006$ S. Karger AG, Basel

\section{Introduction}

Comprehensive treatment of cleft lip and palate (CLP) requires a multidisciplinary approach, including among others, multiple surgeries, speech therapy, psychological support, and dental and orthodontic treatments over the first 18 years of life [1]. However, it seems that all surgical interventions have an impact on the craniofacial 
growth of the young patient and their consequences differ according to the extent of the cleft and the techniques used for its correction [2].

For example, early postnatal repair of cleft lip (CL), which is very important at this stage of life for functional and esthetic reasons, results in suboptimal postoperative maxillary growth. Despite the acceptable surgical results, the surface of the surgical closure of the lip heals with formation of nonelastic scar tissue. This way the lip will function exactly as a band preventing normal maxillary growth development. As a result, these patients will develop a long-term maxillary deficiency, as well as a tendency for anterior crossbites [3]. Another example is early complete palatal repair. Although early complete palatal repair yields very good overall results in speech development, the trauma and the tension of the scar tissue adversely affects the craniofacial growth [4]. Early intervention for cleft palate (CP) stabilizes the two maxillary segments and results in callus formation, which restricts growth in the three planes of space. The maxilla becomes deficient in all three dimensions and the patients develop anterior and/or posterior crossbites [3]. This maxillary deficiency could require not only orthodontic/ orthopedic treatment but also orthognathic surgery, usually with Le Fort osteotomies, when the patient reaches early adulthood. However, recent techniques and better sequencing of bone grafting have significantly reduced the final deformity.

Nowadays, the widespread use of high-resolution ultrasound, although with some limitations, allows a more accurate and earlier diagnosis of congenital anomalies [5]. In addition, the development of more sophisticated methods, not only in prenatal diagnosis, but also in anesthesia and surgery has led to the use of in utero surgical approaches, which allow earlier treatment of selected lifethreatening congenital anomalies, such as congenital diaphragmatic hernia, lower urinary tract obstruction, congenital cystic adenomatoid malformation of the lung, sacrococcygeal teratoma, and twin-twin transfusion Syndrome [6]. Until today, only these anomalies satisfy the criteria set by the IFMSS (International Fetal Medicine and Surgery Society), which a congenital malformation should fulfill for in utero intervention in humans [7]. However, as prenatal diagnosis, medical technology, and the techniques of in utero procedures improve, these surgical approaches are nowadays applied in humans also for non-life-threatening conditions, such as myelomeningocele [8], and they probably could be applied in the future also in CLP patients.
Experimental in utero repair of CLP, which can be performed either after hysterotomy (open approach) or through the endoscopic approach, has captured the interest of craniofacial surgeons, after it was observed that through intervention at the mid-gestational age, soft tissue wound healing in experimental animals could occur without scars [9-14] and bone healing could take place without or with minimal callus formation $[14,15]$. This way, primary or secondary maxillary growth restrictions could be minimized $[9,16-18]$, resulting probably in a reduction or minimal need for secondary surgical interventions or additional treatments after birth, including orthodontics [19].

Consequently, during the last two decades different animal models have been proposed to evaluate in utero repair of cleft-like defects [16-18, 20-28]. Unfortunately, these studies were dealing only with the malformed upper lip soft tissues and with wound healing. The bony alveolar defect, which has been simultaneously created remained untreated and was not considered, although some, but not complete, spontaneous closure could occur.

We hypothesized that a cleft lip and alveolus (CLA) repair in utero would heal without soft tissue scar formation and bone healing will heal without or with minimal callus formation, and therefore primary or secondary maxillary growth restrictions would not occur. To study this hypothesis, we used the mid-gestational sheep model to evaluate maxillary growth following in utero repair, performed with four different approaches including both lip closure and the use of grafts in order to fill the alveolar defect area, of surgically created CLA-like defects by means of three-dimensional (3D) computer tomographic (CT) cephalometric analysis.

\section{Materials and Methods}

The time-dated pregnant sheep were housed 2 days prior to surgery at the animal care facility of the Institute of Experimental Oncology and Therapy Research at the Technical University of Munich. The protocols of this study were reviewed by the Ethical Committee for Animal Experimentation of the District Government of Upper Bavaria (AZ: 211-2531-17/97 \& 209.1/211-2531-42/02), and all animals used were treated in accordance with the current guidelines on animal welfare. There were 2 twin pregnancies and 1 triple. These twins and triplets $(n=4)$ served as nonoperated control animals. In total, 12 fetuses were evaluated following in utero creation and repair of unilateral CLA-like defects.

\section{Surgical Approaches}

The creation of CLA-like defects, graft harvesting, repair of CLA-like defects, as well as closure of the uterus, were performed 
between the 75th and 95th gestational day (term: 145-150 days), according to surgical procedures which have been described in detail elsewhere [14].

\section{Study Groups}

Twelve fetuses were used for the surgical creation of a unilateral CLA-like defect and its subsequent in utero repair, which were assigned into four study groups. For the closure of the alveolar defect, fetal iliac crest bone graft was used in the fetuses of group I $(n=3)$ and was fixed to the maxilla with fibrin sealant (Tissucol ${ }^{\circledR}$, Baxter Germany - Immuno GmbH, Heidelberg, Germany). In the fetuses of group II $(n=2)$, a fetal ulnar graft was used for the alveolar defect closure, which was also fixed to the maxilla with fibrin sealant $\left(\right.$ Tissuco $\left.{ }^{\circledR}\right)$. A fetal ulnar graft was also used in the fetuses of group III $(n=3)$ and was fixed to the maxilla as in group II combined with a Gore-Tex ${ }^{\circledR}$ membrane (TR6Y Gore-Tex ${ }^{\circledR}$ Regenerative Material (membrane) Titanium-Reinforced, W.L. Gore \& Associates $\mathrm{GmbH}$, Putzbrunn, Germany). In the fetuses of group IV $(n=4)$, the bone regenerating bioresorbable material collagenlyophilisate $\left(\right.$ Coloss $^{\circledR}$ Collagen-Lyophilisate) covered also by a Gore-Tex ${ }^{\circledR}$ membrane, was used for the closure of the surgically created alveolar defect. The untreated control group consisted of 4 fetuses.

\section{D-CT Cephalometric Analysis}

Between the 140th-145th gestational day all the animals were euthanized using pentobarbital $\left(\right.$ Narcoren $^{\circledR}$, Rhone-Merieux, Laupheim, Germany); the fetuses were removed, and then their heads were separated. The heads of the fetuses were then CT scanned with the Siemens Somatom AR Star ${ }^{\circledR}$ scanner (Siemens Inc., Erlangen, Germany). CT scanning was performed at $110 \mathrm{kV}$ and $120 \mathrm{~mA}$ with a slice thickness and increment of $1 \mathrm{~mm}$. The CT data presented a scanning matrix size of $512 \times 512$ pixels with a color depth of 12 bits. For the 3D reconstructions, the CT datasets of all 16 skulls were then transferred to a Digital Personal Workstation (Digital Equipment Corporation, Scotland) equipped with a 1.5-GB hard disk and processed by means of the volume rendering and measurement VOXELMAN ${ }^{\circledR}$ software (IMDM, Hamburg, Germany). Following the 3D-CT reconstructions, a 3D-CT cephalometric analysis was performed. In order to evaluate the differences between the left and right (operated/cleft vs. nonoperated/ noncleft side) skull sides in each group as well as the asymmetry between experimental and control groups, 16 landmarks were defined and used (fig. 1, 2, table 1), and 24 linear measurements were performed on the reconstructed skulls (12 on the operated/cleft side and 12 on the nonoperated/noncleft side) (table 2). The landmarks used in this study were derived or modified from a selection of papers dealing with cephalometric measurements on sheep [24, 27 , 29-32] or on rabbit skulls [18, 33] after in utero CLP surgery.

All measurements were performed directly on the reconstructed 3D-CT images by means of the VOXELMAN ${ }^{\circledR}$ software. The landmarks on these $3 \mathrm{D}$ reconstructions were first measured as coordinates (coronal: x-axis, sagittal: y-axis, transversal: z-axis) and then converted into distances using Excel-sheets (Microsoft Excel 97, Microsoft Co., USA) by means of root equations. For example, the distance between the two landmarks $\mathrm{A}\left(\mathrm{X}_{\mathrm{a}}, \mathrm{Y}_{\mathrm{a}}, \mathrm{Z}_{\mathrm{a}}\right)$ and $\mathrm{B}\left(\mathrm{X}_{\mathrm{b}}, \mathrm{Y}_{\mathrm{b}}\right.$, $\mathrm{Z}_{\mathrm{b}}$ ), was calculated by the equation:

$$
\text { Distance } \mathrm{A}-\mathrm{B}=\sqrt{\left(\mathrm{X}_{\mathrm{a}}-\mathrm{X}_{\mathrm{b}}\right)^{2}+\left(\mathrm{Y}_{\mathrm{a}}-\mathrm{Y}_{\mathrm{b}}\right)^{2}+\left(\mathrm{Z}_{\mathrm{a}}-\mathrm{Z}_{\mathrm{b}}\right)^{2}}
$$

Table 1. The landmarks used for the $3 \mathrm{D}-\mathrm{CT}$ cephalometric analysis

\begin{tabular}{|c|c|}
\hline $\begin{array}{l}\text { Land- } \\
\text { marks }\end{array}$ & Definition \\
\hline A & Most anterior point of the os incisivum, operated side \\
\hline B & Most anterior of the os incisivum, nonoperated side \\
\hline $\mathrm{C}$ & Contact point of the fissura interincisiva \\
\hline $\mathrm{C}^{\prime}$ & Contact point of processus palatinae of the incisivum \\
\hline $\mathrm{D}$ & $\begin{array}{l}\text { Most posterior point of the fissura palatine, } \\
\text { operated side }\end{array}$ \\
\hline $\mathrm{E}$ & $\begin{array}{l}\text { Most posterior point of the fissura palatine, nonoperated } \\
\text { side }\end{array}$ \\
\hline $\mathrm{F}$ & Spina nasalis caudalis \\
\hline $\mathrm{L}$ & Incisura intercondylaris \\
\hline Q & Arcus zygomaticus, operated side \\
\hline $\mathrm{R}$ & Processus lacrimalis caudalis, operated side \\
\hline $\mathrm{S}$ & $\begin{array}{l}\text { Prominence of the bone at the upper edge of eye, } \\
\text { operated side }\end{array}$ \\
\hline W & Arcus zygomaticus, nonoperated side \\
\hline $\mathrm{X}$ & Processus lacrimalis caudalis, nonoperated side \\
\hline Y & $\begin{array}{l}\text { Prominence of the bone at the upper edge of eye, } \\
\text { nonoperated side }\end{array}$ \\
\hline $\mathrm{U}$ & $\begin{array}{l}\text { Meeting point of the cranial suture of os parietale and of } \\
\text { os frontale }\end{array}$ \\
\hline V & Meeting point of the cranial suture of os parietale \\
\hline
\end{tabular}

The CT datasets of the skulls and their corresponding 3D reconstructions performed by means of the VOXELMAN ${ }^{\circledR}$ software were additionally used in order to evaluate bone graft healing.

\section{Error of the Method}

The evaluation of accuracy, precision, and methodological error of the used 3D-CT cephalometric analysis was reported elsewhere. ${ }^{1}$

\section{Statistical Analysis}

For the statistical evaluation of the data, the software 'SPSS 10.0 for Windows' (SPSS Inc., Chicago, USA) was used. The data distribution of each variable was first evaluated by means of the onesample Kolmogorov-Smirnov test. According to this evaluation, the following nonparametric tests were used for further statistical evaluation: (a) the Wilcoxon signed-rank test for intragroup comparisons, in order to compare the differences between the left and right (operated/cleft vs. nonoperated/noncleft) skull sides in each group, (b) the multivariate GLM analysis for inter-group comparisons in order to compare the maxillary asymmetry (the difference between the operated/cleft minus the nonoperated/noncleft side) among the four experimental groups, and (c) the Kruskal-Wallis

\footnotetext{
1 Papadopoulos MA, Jannowitz C, Boettcher P, Henke J, Stolla R, Zeilhofer H-F, Kovacs L, Erhardt W, Biemer E, Papadopulos NA: Three-dimensional fetal cephalometry: an evaluation of the reliability of cephalometric measurements based on three-dimensional CT reconstructions and on dry skulls of sheep fetuses. J Craniomaxillofac Surg 2005 [unpubl. data, submitted for publication].
} 
Fig. 1. Diagram of a sheep skull illustrating the landmarks selected for the 3D-CT cephalometric analysis. a Ventral view. b Lateral view. On the lateral view, the landmarks $\mathrm{R}, \mathrm{S}$, and $\mathrm{Q}$ are those positioned on the operated skull side, while X, Y, and W are on the nonoperated skull side. (Adapted from [42]).

Fig. 2. Images of a $3 \mathrm{D}$ reconstructed skull illustrating the landmarks selected for the 3D-CT cephalometric analysis. a Ventral view. b Lateral view. On the lateral view the landmarks R, S, and Q are those positioned on the operated skull side, while $\mathrm{X}, \mathrm{Y}$, and $\mathrm{W}$ are on the nonoperated skull side.
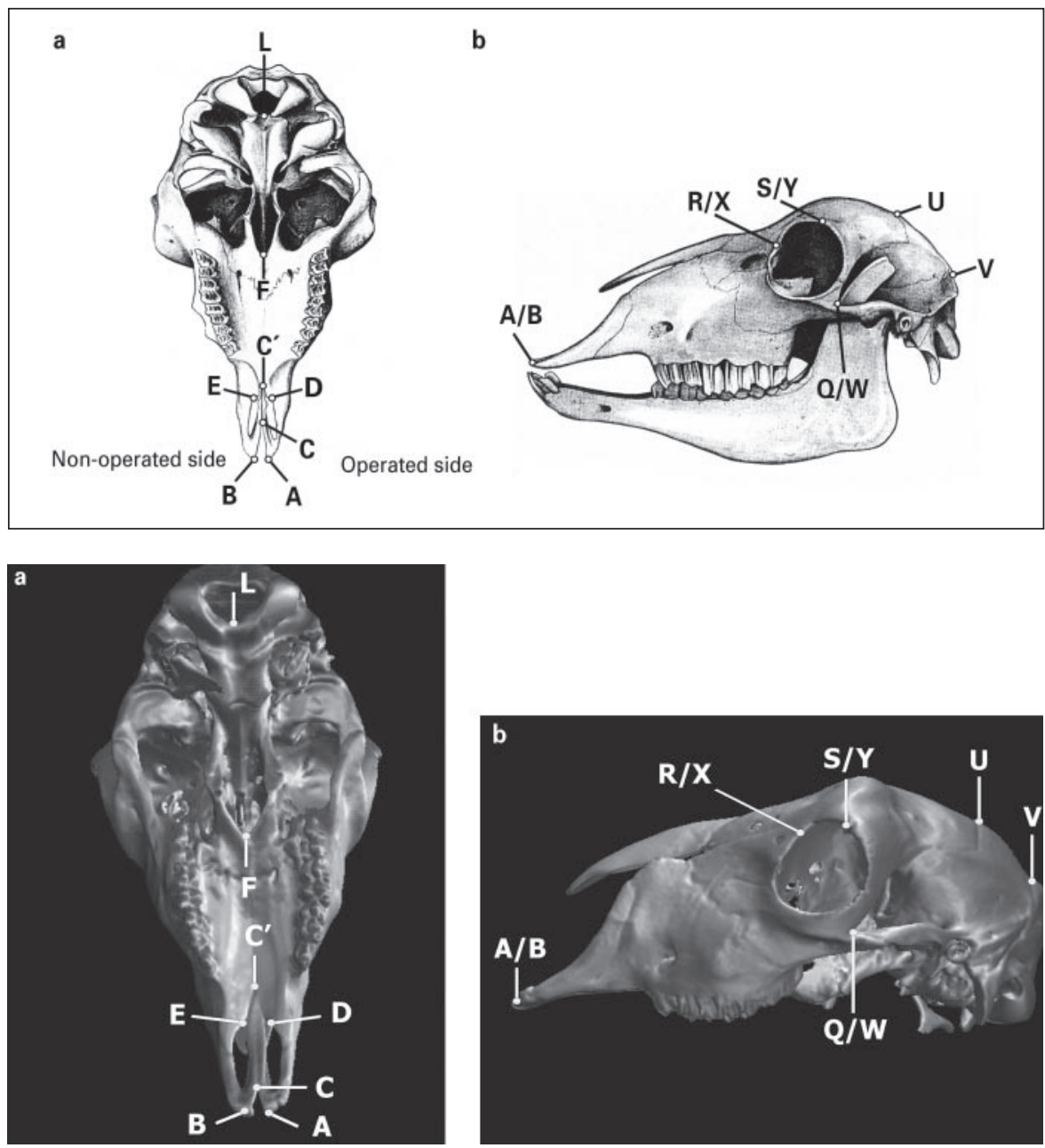

Table 2. The intragroup comparisons of the differences between the left and right skull sides (operated/cleft vs. nonoperated/noncleft) for each group

\begin{tabular}{|c|c|c|c|c|c|c|c|c|c|c|c|c|c|c|c|}
\hline \multicolumn{2}{|c|}{ Variables } & \multicolumn{2}{|c|}{ Group I $(\mathrm{n}=3)$} & \multicolumn{2}{|c|}{ Group II $(\mathrm{n}=2)$} & \multicolumn{2}{|c|}{ Group III $(\mathrm{n}=3)$} & \multicolumn{2}{|c|}{ Group IV $(\mathrm{n}=4)$} & \multicolumn{2}{|c|}{ Control group } & \multicolumn{2}{|c|}{ Groups I-IV $(\mathrm{n}=12)$} & \multicolumn{2}{|c|}{ Groups I-IV $(\mathrm{n}=6)$} \\
\hline OS & NOS & $\begin{array}{l}\text { difference } \\
\text { of means } \\
\text { OS-NOS } \\
(\mathrm{mm})\end{array}$ & $\begin{array}{l}\mathrm{p} \\
\text { value }\end{array}$ & $\begin{array}{l}\text { difference } \\
\text { of means } \\
\text { OS-NOS } \\
(\mathrm{mm})\end{array}$ & $\begin{array}{l}\mathrm{p} \\
\text { value }\end{array}$ & $\begin{array}{l}\text { difference } \\
\text { of means } \\
\text { OS-NOS } \\
(\mathrm{mm})\end{array}$ & $\begin{array}{l}\mathrm{p} \\
\text { value }\end{array}$ & $\begin{array}{l}\text { difference } \\
\text { of means } \\
\text { OS-NOS } \\
(\mathrm{mm})\end{array}$ & $\begin{array}{l}\mathrm{p} \\
\text { value }\end{array}$ & $\begin{array}{l}\text { difference } \\
\text { of means } \\
\text { RS-LS } \\
(\mathrm{mm})\end{array}$ & $\begin{array}{l}\mathrm{p} \\
\text { value }\end{array}$ & $\begin{array}{l}\text { difference } \\
\text { of means } \\
\text { OS-NOS } \\
(\mathrm{mm})\end{array}$ & $\begin{array}{l}\mathrm{p} \\
\text { value }\end{array}$ & $\begin{array}{l}\text { difference } \\
\text { of means } \\
\text { OS-NOS } \\
(\mathrm{mm})\end{array}$ & $\begin{array}{l}\mathrm{p} \\
\text { value }\end{array}$ \\
\hline $\mathrm{A}-\mathrm{C}$ & $\mathrm{B}-\mathrm{C}$ & 0.90 & 0.285 & -1.97 & 0.180 & -0.73 & 0.285 & -1.90 & 0.068 & 0.09 & 1.000 & -0.92 & $0.050^{*}$ & -0.15 & 0.075 \\
\hline$A-D$ & B-E & -0.23 & 1.000 & -0.62 & 0.655 & -0.20 & 0.593 & -2.22 & 0.068 & 0.23 & 0.715 & -0.95 & 0.071 & -0.39 & 0.753 \\
\hline $\mathrm{C}-\mathrm{D}$ & $\mathrm{C}-\mathrm{E}$ & -0.59 & 0.285 & 0.39 & 0.655 & 0.39 & 0.109 & -0.49 & 0.273 & 0.12 & 0.715 & -0.15 & 0.638 & 0.32 & 0.173 \\
\hline $\mathrm{A}-\mathrm{C}^{\prime}$ & $\mathrm{B}-\mathrm{C}^{\prime}$ & 0.36 & 0.593 & -1.19 & 0.180 & -0.61 & 0.285 & -1.75 & 0.068 & 0.10 & 0.465 & -0.84 & $0.045^{*}$ & -0.81 & 0.116 \\
\hline $\mathrm{D}-\mathrm{C}^{\prime}$ & $\mathrm{E}-\mathrm{C}^{\prime}$ & 0.16 & 1.000 & -0.31 & 0.180 & 0.43 & 0.109 & -0.82 & 0.068 & 0.35 & 0.273 & -0.18 & 0.346 & 0.21 & 0.600 \\
\hline $\mathrm{A}-\mathrm{F}$ & $\mathrm{B}-\mathrm{F}$ & -0.10 & 1.000 & -0.60 & 0.180 & -0.44 & 0.285 & -1.52 & 0.068 & 0.17 & 0.465 & -0.74 & 0.060 & -0.50 & 0.173 \\
\hline A-L & B-L & -0.15 & 1.000 & -0.20 & 0.180 & -0.35 & 0.285 & -1.34 & 0.068 & 0.19 & 0.465 & -0.61 & 0.071 & -0.33 & 0.345 \\
\hline$A-R$ & $\mathrm{~B}-\mathrm{X}$ & 0.27 & 1.000 & -2.40 & 0.180 & -1.17 & 0.285 & -1.40 & 0.715 & 0.95 & 0.144 & -1.09 & 0.347 & -0.90 & 0.345 \\
\hline A-S & B-Y & -0.89 & 0.593 & -0.41 & 0.655 & -1.56 & 0.109 & -2.42 & 0.465 & 0.82 & 0.144 & -1.49 & 0.239 & -0.71 & 0.345 \\
\hline $\mathrm{A}-\mathrm{Q}$ & B-W & -0.75 & 1.000 & 0.44 & 0.655 & 0.30 & 0.109 & -1.51 & 0.465 & 0.48 & 0.197 & -0.54 & 1.000 & 0.26 & 0.753 \\
\hline $\mathrm{A}-\mathrm{U}$ & $\mathrm{B}-\mathrm{U}$ & -0.15 & 1.000 & 1.18 & 0.180 & -0.55 & 0.285 & -1.35 & 0.068 & 0.06 & 0.715 & -0.82 & $0.050^{*}$ & -0.72 & 0.116 \\
\hline$A-V$ & $B-V$ & -0.19 & 1.000 & -0.42 & 0.180 & -0.42 & 0.285 & -1.37 & 0.068 & 0.15 & 0.715 & -0.68 & 0.071 & -0.43 & 0.249 \\
\hline
\end{tabular}

OS = Operated side; NOS = nonoperated side; $\mathrm{RS}=$ right side; $\mathrm{LS}=$ left side (Wilcoxon signed-rank test; significant differences at $* \mathrm{p}<0.05$ ).

${ }^{a}$ Groups I-IV (with bone graft healing). 
test for intergroup comparisons, in order to evaluate the maxillary asymmetry between experimental and control groups. In order to increase the statistical power of the analysis, two additional groups were formed: the first one included all operated lambs treated with the four different in utero surgical approaches without taking into consideration whether or not bone graft healing has taken place (groups I, II, III, and IV; $\mathrm{n}=12$ ); the second one included all operated lambs treated with the four different in utero approaches, in which bone graft healing was evident (groups I, II, III, and IV; $\mathrm{n}=$ 6). For all tests the overall statistical level of significance was set at $\mathrm{p}<0.05$.

\section{Results}

The results of the statistical evaluation concerning the intragroup comparisons between the left and right (operated/cleft vs. nonoperated/noncleft) skull sides for each group are shown in table 2 . The intergroup comparisons of the maxillary asymmetry (the difference between the operated/cleft minus the nonoperated/noncleft side) among the four experimental groups are presented in table 3 , while the intergroup comparisons of the maxillary asymmetry between experimental and control groups are shown in table 4.

\section{Discussion}

Data from experimental as well as from clinical studies suggest that the postnatal operative repair of CLP results in maxillary growth inhibition [1]. It has been hypothesized that, at least in part, this is due to scar formation occurring as a result of soft tissue dissection as well as of the multiple surgical procedures used for their treatment.

Experimental in utero repair of CLP has captured the interest of craniofacial surgeons, after it was observed that through an intervention at the mid-gestational age, soft tissue wound healing could occur without scars, and fetal bone healing could take place with minimal or no callus formation [34]. The correct timing of surgical intervention as well as an adequate postoperative treatment period is essential for the in utero treatment of clefts, since scarless wound healing is gestational age-, size-, and tissue dependent.

According to our knowledge, our team was the first that reported results following in utero repair of CLA-like defects, dealing not only with the soft tissues of the malformed upper lip and the subsequent wound healing, but also with bone healing of the alveolar defect [14]. Accord-
Table 3. The intergroup comparisons of the maxillary asymmetry (the difference between the operated/cleft minus the nonoperated/noncleft side) among all experimental groups (multivariate GLM analysis)

\begin{tabular}{lll}
\hline Variables & F statistic & p value \\
\hline$(A-C)-(B-C)$ & 3.392 & 0.074 \\
$(A-D)-(B-E)$ & 2.619 & 0.123 \\
$(C-D)-(C-E)$ & 0.339 & 0.798 \\
$\left(A-C^{\prime}\right)-\left(B-C^{\prime}\right)$ & 2.005 & 0.192 \\
$\left(D-C^{\prime}\right)-($ E-C $)$ & 0.338 & 0.799 \\
$(A-F)-(B-F)$ & 1.723 & 0.239 \\
$(A-L)-(B-L)$ & 2.362 & 0.147 \\
$(A-R)-(B-X)$ & 0.509 & 0.687 \\
$(A-S)-(B-Y)$ & 1.761 & 0.232 \\
$(A-Q)-(B-W)$ & 0.932 & 0.468 \\
$(A-U)-(B-U)$ & 0.715 & 0.570 \\
$(A-V)-(B-V)$ & 1.729 & 0.238 \\
\hline
\end{tabular}

Table 4. The intergroup comparisons of the maxillary asymmetry (the difference between the operated/cleft minus the nonoperated/ noncleft side) between experimental and control groups (KruskalWallis test)

\begin{tabular}{|c|c|c|c|c|}
\hline \multirow[t]{2}{*}{ Variables } & \multicolumn{2}{|c|}{$\begin{array}{l}\text { Groups I-IV } \\
\text { vs. control group }\end{array}$} & \multicolumn{2}{|l|}{ Groups I-IV ${ }^{\mathrm{a}}$} \\
\hline & $\begin{array}{l}\text { difference of } \\
\text { means }(\mathrm{mm})\end{array}$ & $\mathrm{p}$ value & $\begin{array}{l}\text { difference of } \\
\text { means }(\mathrm{mm})\end{array}$ & $\mathrm{p}$ value \\
\hline$(\mathrm{A}-\mathrm{C})-(\mathrm{B}-\mathrm{C})$ & 1.14 & $0.015^{*}$ & 0.92 & 0.088 \\
\hline$(A-D)-(B-E)$ & 0.81 & 0.182 & 0.20 & 0.831 \\
\hline$(C-D)-(C-E)$ & -0.06 & 0.585 & -0.13 & 0.522 \\
\hline$\left(\mathrm{A}-\mathrm{C}^{\prime}\right)-\left(\mathrm{B}-\mathrm{C}^{\prime}\right)$ & 0.94 & $0.013^{*}$ & 0.70 & 0.069 \\
\hline$\left(\mathrm{D}-\mathrm{C}^{\prime}\right)-\left(\mathrm{E}-\mathrm{C}^{\prime}\right)$ & 0.01 & 0.716 & -0.03 & 1.000 \\
\hline$(\mathrm{A}-\mathrm{F})-(\mathrm{B}-\mathrm{F})$ & 0.82 & $0.029 *$ & 0.38 & 0.201 \\
\hline$(\mathrm{A}-\mathrm{L})-(\mathrm{B}-\mathrm{L})$ & 0.66 & 0.060 & 0.19 & 0.394 \\
\hline$(\mathrm{A}-\mathrm{R})-(\mathrm{B}-\mathrm{X})$ & 1.48 & 0.129 & 0.27 & 0.522 \\
\hline$(\mathrm{A}-\mathrm{S})-(\mathrm{B}-\mathrm{Y})$ & 2.33 & $0.039 *$ & 0.85 & 0.136 \\
\hline$(\mathrm{A}-\mathrm{Q})-(\mathrm{B}-\mathrm{W})$ & 1.76 & 0.332 & 0.76 & 0.669 \\
\hline$(\mathrm{A}-\mathrm{U})-(\mathrm{B}-\mathrm{U})$ & 1.05 & $0.008 * *$ & 0.76 & $0.033^{*}$ \\
\hline$(\mathrm{A}-\mathrm{V})-(\mathrm{B}-\mathrm{V})$ & 0.76 & $0.039 *$ & 0.30 & 0.240 \\
\hline
\end{tabular}

Significant differences at $* \mathrm{p}<0.05$ and $* * \mathrm{p}<0.01$.

${ }^{a}$ Groups I-IV (with bone graft healing) vs. control group.

ing to the results of our previous study, we concluded that in utero repaired CLA-like defects heal without scar and callus formation, and we therefore hypothesized that primary or secondary maxillary growth restriction would not occur. In addition, the reconstruction of an intact oral 
muscular sphincter could provide a more normal 'functional matrix' for the growing fetus. We therefore decided to evaluate maxillary growth following in utero repair of surgically created CLA-like defects, including both lip closure and the use of grafts in order to fill the alveolar defect area, by means of 3D-CT cephalometric analysis. This study is the first to report results of maxillary growth in sheep fetuses following in utero repair, including both lip closure and the use of grafts in order to reconstruct the malformed alveolar area.

During the last two decades different animal models have been proposed to evaluate in utero treatment of cleft-like defects [19]. In this study, the mid-gestational pregnant sheep model was used for the creation of the CLA-like defects for reasons already described elsewhere $[13,14,19,22,35]$.

The evaluation of the maxillary growth, performed in this study by means of 3D cephalometric analysis on 3D$\mathrm{CT}$ reconstructions, aimed to facilitate additional investigations of the heads of the fetuses, such as histological ones. For this purpose, a 3D-CT cephalometric analysis was used, which was previously developed for the postsurgical maxillary growth evaluation of lambs operated in utero for the correction of CLA-like defects. The authors evaluated the reliability and accuracy of this analysis by comparing cephalometric measurements based on 3D-CT reconstructions and direct cephalometric measurements on the corresponding dry skulls of lambs, and they concluded that the measurements performed directly on the skulls as well as on the corresponding 3D-CT reconstructions presented a very good correlation. Furthermore, they concluded that cephalometric analysis on the 3D-CT reconstructed skulls included less identification errors and seemed to be an accurate and reliable method that could be regarded as equivalent as or even more advantageous than direct cephalometry on dry skulls.

In our current data, no statistically significant differences were found in the comparison between the operated/cleft and nonoperated/noncleft sides of the fetuses in the experimental groups, or in the control group (table 2) (fig. 3, 4). The same comparison between the operated and nonoperated sides of all the experimental fetuses $(n=12)$ revealed that only 3 out of 12 variables presented significant differences. On the contrary, when we took into consideration only the fetuses in which bone graft healing was evident following in utero repair of the cleft alveolar defect $(n=6)$, no significant differences between the two sides were observed.
Furthermore, the evaluation of the maxillary asymmetry (the difference between the operated/cleft minus the nonoperated/noncleft side) of the four different in utero approaches among themselves again revealed no statistically significant differences (table 3 ). Finally, the intergroup comparisons between operated and control animals revealed that when all the operated animals $(\mathrm{n}=$ 12) were compared to the nonoperated control animals $(n=4), 6$ variables presented significant differences, while when only the operated animals were taken into consideration, in which bone graft healing was evident $(n=6)$, only one significant difference was observed (table 4).

These results indicate that none of the four different approaches used for the in utero correction of CLA-like defects in the mid-gestational sheep model seems to affect significantly the postsurgical maxillary growth. Furthermore, it could be stated that when bone graft healing takes place following in utero repair of cleft alveolus-like defects, a tendency of normal maxillary growth can be observed.

The small number of animals in our study suggests that the power of the statistical tests used may be insufficient to draw meaningful conclusions. However, most of the $p$ values were very large (tables 2-4). Although the number of animals in each group was small, the total number of 16 lambs (experimental and controls) is a large number of animals to be sacrificed [27].

Attempts to evaluate postsurgical maxillary growth following in utero interventions either performed by means of direct measurements on the skulls (dry skull cephalometric analysis) or indirectly by means of 3D-CT cephalometric analysis have already been published. For this purpose, both the rabbit [18, 36, 37], as well as the sheep model [27, 29-32, 38], have been used, while many of the above investigations are dealing with repair of $\mathrm{CL}$ or CLP defects [18, 23, 27, 29, 31, 32].

Dodson et al. [23] presented in 1991 the first rabbit model for the evaluation of postnatal maxillary growth following in utero repair of CLA defects. The results of the direct cephalometric analysis indicated that the animals that underwent an in utero repair of CLA defects, exhibited no significant decrease in maxillary length and width when they were compared with the control animals. Further, Kaban et al. [18] presented long-term (26th postnatal week) clinical and cephalometric results following fetal CL repair using also the same model. The animals with unrepaired CL developed mild to severe asymmetry of the nose, lip, alveolus and of the teeth, with no changes of the nasal bones. By contrast, the in utero operated animals showed only a slight asymmetry of the nose 



Fig. 3. Representative 3D-CT skull reconstructions of fetuses following intrauterine correction of CLA-like defects. a A fetus that has received an iliac crest graft for the alveolar defect closure (group I). A normal maxillary growth and absence of asymmetry of the maxilla can be observed. b A fetus that has received an ulnar graft. A slight deviation of the maxilla is obvious (group II). c A fetus that has received an ulnar graft in combination with a Gore-Tex ${ }^{\circledR}$ membrane (group III). Minimal affection of the maxillary growth as well as little artifact due to the titanium-reinforced membrane is present. d A fetus that has received collagen-lyophilisate in combination with a Gore-Tex ${ }^{\circledR}$ membrane (group IV). A significant deviation of the maxilla can be observed, resulting from the fact that no bone graft healing has taken place.

Fig. 4. A representative 3D-CT skull reconstruction of a nonoperated fetus of the control group. Compared to operated fetuses represented in figure 3 , a normal growth and an almost absolute absence of asymmetry of the maxilla can be observed.

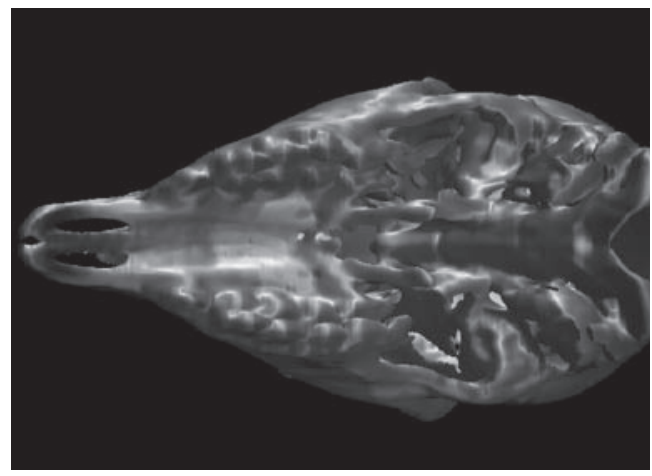


and a mild deviation of the nasal septum. The dry skull cephalometric analysis revealed that at the end of facial growth, there were no statistically significant differences among the three study groups for the variables defining anterior maxillary length, premaxillary width, as well as anterior and posterior maxillary width.

As in our study, the sheep model has also been used by other investigators trying to evaluate postsurgical craniofacial growth following in utero repair of CLP-like defects. In order to examine the impact of scar formation on craniofacial growth after iatrogenic cleft palate repair, Canady et al. [27] performed a CT cephalometric evaluation of sheep fetuses operated in the hard and soft palate during the period of scarless healing as well as fetuses during the period of healing with scar formation. The authors found no significant differences between the treatment groups and concluded that in utero cleft palate repair, with or without scarring, resulted in normal maxillary growth in the 1-month-old lamb. In addition, Smith et al. [29] evaluated the long-term facial growth after in utero repair of CL defects in sheep fetuses using both endoscopic as well as an open hysterotomy technique and found that the in utero repair of CL-like defects appeared to improve facial growth of the lambs. The evaluation was performed by means of measurements on 3D-CT scans 1 week after birth, and by means of both direct measurements on dry skulls and on 3D-CT scans after 6 months of age. In a further long-term study, Stelnicki et al. [32] evaluated maxillary growth following in utero CL surgery in sheep fetuses 9 months after birth and compared it with an identical CL repair performed on infant lambs, using also direct cephalometric measurements on dry skulls. The authors found that there was no evidence of maxillary growth inhibition in the in utero CL repair group. By contrast, a significant inhibition in sagittal maxillary development was observed in the animals that underwent postnatal CL repair.

There seems to be a consensus that when cleft repair takes place postnatally, the unavoidable scar formation has a large influence on the maxillary growth. Furthermore, the results of all the aforementioned investigations performed either on rabbit or on sheep fetuses are in agreement with the results of our study, confirming the fact that maxillary growth following in utero repair of CLA-like defects is not significantly affected, because the soft tissues can heal without scars and bone can heal without callus formation. According to the findings of our study as well as to similar studies, the in utero repair of surgically created CLA-like defects seems to be more advantageous compared to postnatal repair. However, all in utero approaches include the disadvantages of an increased preterm labor rate and increased risk of prenatal mortality, factors that have prevented the widespread use of these techniques [30, 39]. Furthermore, moral and ethical issues arise when an in utero intervention is proposed to be applied for non-life-threatening conditions, such as CLP.

Finally, according to Canady et al. [27], there are still some questions to be answered concerning in utero cleft repair that could also be applied in our study, such as: 'What effects of surgery would be seen if the animals were followed for a longer period of time postnatally? Is the sheep a good animal model for study of human craniofacial growth? Is iatrogenic cleft in any way comparable to genetically induced clefting?'

In order to answer these questions, further experimental investigations are needed to improve the in utero techniques for CLP repair, keeping always in mind that we may never be able to find an optimal and safe approach for the treatment of non-life-threatening facial deformities in humans. Therefore, we intend to continue intensive research on the in utero repair of clefts using as our next step the delayed repair model, which simulates more closely the clinical situation of patients with CLP, as proposed by Hedrick et al. [35]. According to this model the cleft defect is created on the 60th gestational day and repaired on the 75th gestational day. In addition, a 6-month postnatal follow-up evaluation is planned, in hope of obtaining a more relevant evaluation of long-term maxillary growth effects. Allografts and bioresorbable bone-regenerating materials, such as bone morphogenetic protein-2, will also be considered to repair the cleft alveolus. Furthermore, we plan to use feto-endoscopic approaches, which compared to the open surgical approaches, will decrease substantially the preterm labor rate and the risk of prenatal mortality [13, 39-41].

\section{Acknowledgments}

This study was supported by the Research Council of the Faculty of Medicine at the Technical University Munich (Konto für klinische Forschung der Medizinischen Fakultät der Technischen Universität München, KKF F 5-01/grant No 8744551).

We wish to thank the members of our intrauterine surgery team: Roswitha Bergmeyer, Heike Boos, DVM, Dr. med. vet., Thomas Brill, DVM, Dr. med. vet., Regina Hertel, B. Pichotka, Margit Leucz, Veronica Pohlheimer, and Ingo Pragst, DVM, Dr. med. vet. of the Institute of Experimental Oncology and Therapy Research, and Peter Graf, MD, PhD, Dr. med., Dr. med. habil. of the Department of Plastic \& Reconstructive Surgery at the Technical University of Munich for their excellent animal care, technical assistance, 
help on setting up this study, as well as for their fruitful discussions and reviewing the manuscript. Susanne Hipper, photographer of the Department of Plastic and Reconstructive Surgery at the Technical University of Munich, is acknowledged for the photographic documentation. The authors would like to thank also Mrs. StorzReling, and Mr. Gerhard Steinrücken (Karl Storz GmbH \& Co.,
Germany), Baxter Germany - Immuno GmbH, Mrs. Maria Behrens (Ossacur AG, Germany), Mr. Frank Menke (Auto Suture Germany $\mathrm{GmbH}$ ), and Mrs. Ulrike Neckermann Mr. Steffen Kahdemann (W.L. Gore \& Associates GmbH, Germany), and Matthias Riedl, Jörn Scholz and Andreas Sowa (Ethicon GmbH, Germany) for their generous support.

\section{References}

1 Papadopulos NA, Papadopoulos MA: Can intrauterine surgery improve the quality of life of cleft lip and palate patients? Hippokratia 2003; 7:59-80.

2 Waite DE, Kersten RB: Residual alveolar and palatal clefts; in Bell WH, Proffit WR, White RP (eds): Surgical correction of dentofacial deformities. Philadelphia, WB Saunders, 1980, vol 2, pp 1329-1367.

3 Proffit WR, Turvey TA: Special problems in cleft-palate patients; in Proffit WR, White RP (eds): Surgical orthodontic treatment. St. Louis, Mosby, 1991, pp 625-659.

4 Molsted K: Treatment outcome in cleft lip and palate: issues and perspectives. Crit Rev Oral Biol Med 1999; 10:225-239.

5 Papadopoulos MA, Christou PK, Athanasiou AE, Boettcher P, Zeilhofer HF, Sader S, Papadopulos NA: Three-dimensional craniofacial reconstruction imaging. Oral Surg Oral Med Oral Pathol Oral Radiol Endod 2002;93:382_ 393.

6 Harrison MR, Anderson J, Rosen MA, Ross NA, Hendrickx AG: Fetal surgery in the primate. I. Anesthetic, surgical, and tocolytic management to maximize fetal-neonatal survival. J Pediatr Surg 1982;17:115-122.

7 Harrison MR: Professional considerations in fetal treatment; in Harrison MR, Golbus MS, Filly RA (eds): The Unborn Patient. Philadelphia, WB Saunders, 1991, pp 8-13.

8 Bruner JP, Tulipan NB, Richards WO, Walsh WF, Boehm FH, Vrabcak EK: In utero repair of myelomeningocele: a comparison of endoscopy and hysterotomy. Fetal Diagn Ther 2000; 15:83-88.

9 Adzick NS, Harrison MR, Glick PL, Beckstead JH, Villa RL, Scheuenstuhl H, Goodson WH, 3rd: Comparison of fetal, newborn, and adult wound healing by histologic, enzyme-histochemical, and hydroxyproline determinations. J Pediatr Surg 1985;20:315-319.

10 Adzick NS, Longaker MT: Animal models for the study of fetal tissue repair. J Surg Res 1991; 51:216-222.

11 Longaker MT, Whitby DJ, Adzick NS, Crombleholme TM, Langer JC, Duncan BW, Bradley SM, Stern R, Ferguson MW, Harrison MR: Studies in fetal wound healing. VI. Second and early third trimester fetal wounds demonstrate rapid collagen deposition without scar formation. J Pediatr Surg 1990;25:63-69.

12 Longaker MT, Adzick NS: The biology of fetal wound healing: a review. Plast Reconstr Surg 1991;87:788-798
13 Papadopulos NA, Zeilhofer HF, Papadopoulos MA, Feussner H, Henke J, Kovacs L, Horch $\mathrm{HH}$, Biemer E: Tierexperimentelle endoskopische intrauterine Chirurgie bei kraniofazialen Fehlbildungen am Beispiel der LippenKiefer-Gaumen-Spalten [Experimental endoscopic intrauterine surgery for craniofacial malformations such as the cleft lip and palate]. Mund Kiefer Gesichtschir 2003;7:7075 .

14 Papadopulos NA, Papadopoulos MA, Zeilhofer HF, Boos H, Henke J, Erhardt W, Boettcher P, Stolla R, Kovacs L, Biemer E: Intrauterine autogenous fetal bone transplantation for the repair of cleft like defects in the midgestational sheep model. J Craniomaxillofac Surg 2004;32:199-210.

15 Longaker MT, Moelleken BR, Cheng JC, Jennings RW, Adzick NS, Mintorovich J, Levinsohn DG, Gordon L, Harrison MR, Simmons DJ: Fetal fracture healing in a lamb model. Plast Reconstr Surg 1992;90:161-171; discussion 172-173.

16 Hallock GG: In utero cleft lip repair in $\mathrm{A} / \mathrm{J}$ mice. Plast Reconstr Surg 1985;75:785-790.

17 Sullivan WG: In utero cleft lip repair in the mouse without an incision. Plast Reconstr Surg 1989;84:723-730; discussion 731-732.

18 Kaban LB, Dodson TB, Longaker MT, Stern M, Umeda H, Adzick S: Fetal cleft lip repair in rabbits: long-term clinical and cephalometric results. Cleft Palate Craniofac J 1993;30: 13-21.

19 Papadopoulos MA, Jannowitz C, Christou P, Henke J, Boettcher P, Sader R, Kovacs L, Zeilhofer H-F, Biemer E, Papadopulos NA: Fetal surgical treatment of cleft-lip and palate: a real possibility or a utopia? Hellenic Plastic Surgery 2002;1:191-203.

20 Hallock GG, Rice DC, McClure HM: In utero lip repair in the rhesus monkey: an update. Plast Reconstr Surg 1987;80:855-858.

21 Longaker MT, Dodson TB, Kaban LB: A rabbit model for fetal cleft lip repair. J Oral Maxillofac Surg 1990;48:714-719.

22 Longaker MT, Stern M, Lorenz P, Whitby DJ, Dodson TB, Harrison MR, Adzick NS, Kaban LB: A model for fetal cleft lip repair in lambs. Plast Reconstr Surg 1992;90:750-756.

23 Dodson TB, Schmidt B, Longaker MT, Kaban LB: Fetal cleft lip repair in rabbits: postnatal facial growth after repair. J Oral Maxillofac Surg 1991;49:603-611.
24 Stern M, Dodson TB, Longaker MT, Lorenz HP, Harrison MR, Kaban LB: Fetal cleft lip repair in lambs: histologic characteristics of the healing wound. Int J Oral Maxillofac Surg 1993;22:371-374.

25 Stern M, Schmidt B, Dodson TB, Stern R, Kaban LB: Fetal cleft lip repair in rabbits: histology and role of hyaluronic acid. J Oral Maxillofac Surg 1992;50:263-268; discussion 269.

26 Canady JW, Landas SK, Morris H, Thompson SA: In utero cleft palate repair in the ovine model. Cleft Palate Craniofac J 1994;31:3744.

27 Canady JW, Thompson SA, Colburn A: Craniofacial growth after iatrogenic cleft palate repair in a fetal ovine model. Cleft Palate Craniofac J 1997;34:69-72.

28 Evans ML, Oberg KC, Kirsch W, Zhu YH, Hardesty RA: Intrauterine repair of cleft liplike defects in lambs with a novel microclip. J Craniofac Surg 1995;6:126-131.

29 Smith R, Xiao H, Jackson IT, Rhee C, Sanus G: Long-term facial growth after endoscopic and open in-utero repair of a cleft lip model in the fetal lamb. Eur J Plast Surg 1997;20:2732 .

30 Stelnicki EJ, Vanderwall K, Harrison MR, Longaker MT, Kaban LB, Hoffman WY: The in utero correction of unilateral coronal craniosynostosis. Plast Reconstr Surg 1998;101:287296.

31 Stelnicki EJ, Vanderwall K, Hoffman WY, Szabo Z, Harrison MR, Foster R, Longaker MT: Adverse outcomes following endoscopic repair of a fetal cleft lip using an ovine model. Cleft Palate Craniofac J 1998;35:425-429.

32 Stelnicki EJ, Lee S, Hoffman W, Lopoo J, Foster R, Harrison MR, Longaker MT: A longterm, controlled-outcome analysis of in utero versus neonatal cleft lip repair using an ovine model. Plast Reconstr Surg 1999;104:607615 .

33 Bardach J, Mooney M, Giedrojc-Juraha ZL: A comparative study of facial growth following cleft lip repair with or without soft-tissue undermining: an experimental study in rabbits. Plast Reconstr Surg 1982;69:745-754.

34 Huhn EA, Jannowitz C, Boos H, Papadopulos MA, Zeilhofer H-F, Henke J, Müller D, Kovacs L, Biemer E, Papadopulos NA: Fetale Wundheilung: Aktueller Stand und neue Perspektiven [Fetal wound healing: current status and new perspectives]. Chirurg 2004;75:498507 
35 Hedrick MH, Rice HE, Vander Wall KJ, Adzick NS, Harrison MR, Siebert J, Hoffman WY, Longaker MT: Delayed in utero repair of surgically created fetal cleft lip and palate. Plast Reconstr Surg 1996;97:900-905; discussion 906-907.

36 Engdahl E: Bone regeneration in maxillary defects. An experimental investigation on the significance of the periosteum and various media (blood, surgical, bone marrow and bone grafts) on bone formation and maxillary growth. Scand J Plast Reconstr Surg 1972;8:1-79.

37 Longaker M, Kaban L: Fetal models for craniofacial surgery: cleft lip/palate and craniosynostosis; in Adzick S, Longaker M (eds): Fetal Wound Healing. New York, Elsevier Scientific Press, 1991, pp 95-125.
38 Levine JP, Bradley JP, Shahinian HK, Longaker MT: Nasal expansion in the fetal lamb: a first step toward management of cleft nasal deformity in utero. Plast Reconstr Surg 1999; 103:761-767.

39 Papadopulos NA, Deprest JA, Dumitrascu I, Miserez M, Yesildaglar N, Vandenberghe K, Lerut TE: Endoskopische fetale Chirurgie: eine neue perspektive in der fetalen Therapie? [Endoscopic fetal surgery: a new perspective in fetal therapy?] Sozialpaediatr Kinder Jugendheilkd 2000;22:14-22.
40 Papadopulos NA, Dumitrascu I, Ordonez JL, Decaluwe H, Lerut TE, Barki G, Deprest JA: Fetoscopy in the pregnant rabbit at midgestation. Fetal Diagn Ther 1999;14:118-121.

41 Papadopulos NA, Klotz S, Henke J, Kovacs L, Brill T, Erhardt W, Biemer E: Chirurgische Verschlussmethoden von fetoskopisch erzeugten Membrandefekten am mittelträchtigen Kaninchenmodell [Surgical closure methods for fetoscopic created membrane defects in the midgestational rabbit model]. Geburtsh Frauenheilkd 2003;63:651-657.

42 Popesko P: Schaf, Ziege; in Popesko P (ed). Atlas der topographischen Anatomie der Haustiere. Vol I, Kopf und Hals. Stuttgart, Enke Verlag, 1979, Vol 62, p 78 